Article

\title{
Antifungal Effects of Rhizospheric Bacillus Species Against Bayberry Twig Blight Pathogen Pestalotiopsis versicolor
}

\author{
Md. Arshad Ali $\left.{ }^{1,+}{ }^{(}\right)$, Haiying Ren ${ }^{2,+}$, Temoor Ahmed $^{1}$, Jinyan Luo ${ }^{3}$, Qianli An ${ }^{1}(\mathbb{D}$, \\ Xingjiang $\mathrm{Qi}^{2}$ and $\mathrm{Bin} \mathrm{Li}^{1, *(\mathbb{C})}$ \\ 1 State Key Laboratory of Rice Biology and Ministry of Agriculture Key Lab of Molecular Biology of Crop \\ Pathogens and Insects, Institute of Biotechnology, Zhejiang University, Hangzhou 310058, China; \\ alibau201@gmail.com (M.A.A.); temoorahmed@zju.edu.cn (T.A.); an@zju.edu.cn (Q.A.) \\ 2 The Institute of Horticulture, Zhejiang Academy of Agricultural Sciences, Hangzhou 310021, China; \\ renhy@zaas.ac.cn (H.R.); qixj@zaas.ac.cn (X.Q.) \\ 3 Department of Plant Quarantine, Shanghai Extension and Service Center of Agriculture Technology, \\ Shanghai 201103, China; toyanzi@126.com \\ * Correspondence: libin0571@zju.edu.cn; Tel.: +86-571-88982412 \\ + These authors contributed equally to this work.
}

Received: 19 October 2020; Accepted: 11 November 2020; Published: 18 November 2020

\begin{abstract}
Bayberry is an attractive, nutritious, and popular fruit in China. The plant fungal pathogen Pestalotiopsis versicolor $\mathrm{XJ} 27$ is the causative agent of bayberry twig blight disease, which severely affects bayberry production. Traditional control techniques, such as chemical fungicides, are being used to control this disease; however, these techniques cause environmental and health hazards. In this study, we screened sweet potato rhizospheric bacteria with biocontrol potentials against P. versicolor XJ27, the bayberry twig blight pathogen. Ten isolates showed inhibition; Bacillus siamensis S3 and Bacillus tequilensis S5 showed the highest fungal growth inhibition. The antagonistic bacterial culture suspensions of S3 and S5 inhibited the mycelial growth by $82.9 \%$ and $76.2 \%$, respectively. Their extracellular culture filtrates had mycelial growth inhibition of $86.8 \%$ and $82.2 \%$, respectively. In detached leaf assay, the extracellular culture filtrates of S3 and S5 inhibited the size of the leaf lesion by $82.3 \%$ and $76.2 \%$, respectively. SEM and TEM imaging showed a severe hyphal-damaged structure caused by the antagonistic bacteria. The fungal inhibition mechanisms might employ the hydrolytic enzymes and lipopeptides produced by the bacteria. Both the S3 and S5 have chitinase and protease activity; they produce a series of lipopeptides such as surfactin, iturin, and mycosubtilin. Therefore, we can suggest these bacteria as biocontrol agents for bayberry twig blight disease as an alternative to fungicides based upon their attributes of antifungal activity.
\end{abstract}

Keywords: biocontrol; P. versicolor XJ27; bayberry twig blight; rhizospheric bacteria

\section{Introduction}

Bayberry (Myrica rubra) is a fruit plant in tropical and subtropical zones; its origin is eastern Asia [1,2]. Bayberry is known as "precious southern Yangtze fruit of early summer" for its attractive color and flavor [1,3]. It can be eaten as fresh fruit or some delicious food products like jelly, jam, juice, wine, and other pastries can be prepared from bayberry for consumption. Bayberry contains high levels of bioactive compounds such as anthocyanins and flavonols, with high antioxidant actions. In China, this is a popular southern Yangtze fruit during summer, as well as a good source of natural antioxidants. This fruit has drawn attention for containing a high amount of flavonoids, which is 
beneficial for human health [4]. A considerable amount of various amino acids was also identified in bayberry juice [5].

Bayberry is a popular plant that is cultivated commercially in various locations of China, mostly in the provinces of Fujian, Guizhou, Sichuan, Yunnan, and Zhejiang. As it is an economically important fruit crop, mountain-dwelling farmers rely on the cultivation and selling of bayberry fruits as a good source of their family income. A disease called twig blight has appeared on the fruit trees, causing damage to the bayberry orchards in the Zhejiang area, covering 6000 ha by 2011. The dark brown lesion can extend to the whole twig and plant, causing xylem discoloration. The infected plants may die within one to four years [6]. Pestalotiopsis mangiferae and P. vismiae were identified as pathogens of bayberry twig blight [6]. Another two major fungal pathogens, P. versicolor and P. microspore, were identified in bayberry in Zhejiang, the southern area of China [7]. Later, five fungal species, namely, Epicoccum sorghinum, Neofusicoccum parvum, Lasiodiplodia theobromae, Nigrospora oryzae, and P. myricae, were reported to cause the disease [8]. The researchers screened fungicides such as pyraclostrobin, mancozeb, prochloraz (copper salt), 15\% difenoconazole $+15 \%$ propiconazole, iprodione, thiophanate-methyl, tebuconazole, difenoconazole, azoxystrobin, chlorothalonil, myclobutanil, matrine, boscalid, hymexazol, dithianon, and carbendazim against those pathogens. They also conducted a preliminary biocontrol experiment through a dual culture assay using $B$. velezensis and fungi. Nonetheless, a detailed study of biocontrol of bayberry twig blight has yet to be done.

There are various existing methods to manage plant disease incidences, such as cultural operations and the use of disease-tolerant varieties, but all attempts have not yet been sufficient to eradicate these pathogens. Therefore, the current agriculture practices are mostly dependent on chemical control. The excessive use of chemical pesticides has toxic effects on both environmental and human health [9]. To overcome this situation, the biocontrol of phytopathogens is becoming more popular. Scientists are trying to escape this harmful situation and transition to eco-friendly, hygienic, and safer alternative methods of plant pathogen control [10]. The augmentation of biological means for pathogen control is a potential alternative to chemical control methods.

The rhizosphere is an important habitation zone of beneficial bacteria for plants, called plant-growth-promoting rhizobacteria (PGPR). These bacteria can help plants by producing growth promoting phytohormones, increasing nutrient uptake, solubilizing inorganic phosphates, and nitrogen fixation. They can also restrict pathogens, which ultimately results in indirect plant growth promotion [11]. Hence, these bacteria can be exploited to antagonize several fungal pathogens as an alternative to chemical fungicides. Many biocontrol agents have been identified, including the genera Bacillus [12], Pseudomonas [13], and Streptomyces [14].

Many Bacillus species have been used as biocontrol agents $[15,16]$. The most commonly investigated biocontrol strains belong to B. amyloliquefaciens, B. licheniformis, and B. subtilis. The direct mechanisms of pathogen control may occur through various means, like the production of hydrolytic enzymes, antifungal compounds, lipopeptides, or antibiotics. Indirectly, these bacteria can induce systemic resistance against pathogens $[17,18]$. Several bacterial genera, such as Bacillus, Paenibacillus, Sphingobium, Novosphingobium, Rhizobium, Caulobacter, Stenotrophomonas, Chitinophaga, Flavobacterium, and Burkholderia, were detected as endophytes of sweet potato and were also found at the rhizospheric zone of sweet potato [19-22]; however, very little study has been done to exploit these bacteria in the biocontrol of plant pathogenic fungi. Therefore, based upon the above discussion, the present study is performed to assess the biocontrol potential and mechanisms of rhizospheric $B$. tequilensis and $B$. siamensis bacteria that could antagonize a potential fungal pathogen, $P$. versicolor $\mathrm{XJ} 27$, that causes twig blight of bayberry plant. 


\section{Materials and Methods}

\subsection{Collection of Fungal Pathogen and Growth Medium}

The fungal pathogen P. versicolor XJ27, one of the causal agents of bayberry twig blight disease, was collected from the Institute of Horticulture, Zhejiang Academy of Agricultural Sciences, China. For routine cultivation, the fungus was grown on potato dextrose agar (PDA; potato infusion $200 \mathrm{~g}$, glucose $20 \mathrm{~g}$, and agar $20 \mathrm{~g}$ per liter, $\mathrm{pH} 5.6 \pm 0.2$ ) media at $28^{\circ} \mathrm{C}$ for seven days.

\subsection{Isolation of Rhizospheric Bacteria}

Soil samples were collected from the rhizospheric zone of a sweet potato cultivated field, Hangzhou, China. Homogeneous soil samples were prepared by crushing and sieving the rhizospheric soils. Ten grams of soil samples were weighed and used for analysis, according to Cui et al. [23], with some modifications. In brief, $10 \mathrm{~g}$ of soil samples were kept in $250 \mathrm{~mL}$ Erlenmeyer flasks and kept in $100 \mathrm{~mL}$ of $\mathrm{ddH}_{2} \mathrm{O}$. Flasks were kept in a shaker at $200 \mathrm{rpm}$ for one hour. Some glass beads were added to the flasks to facilitate the agitation of soil suspension. Then, ten-fold serial dilutions were prepared from soil suspension, and $100 \mu \mathrm{L}$ of diluted samples were poured on nutrient agar (NA; beef extract $3 \mathrm{~g}$, glucose $2.5 \mathrm{~g}, \mathrm{NaCl} 5 \mathrm{~g}$, tryptone $10 \mathrm{~g}$, and agar $15 \mathrm{~g}$ per liter, $\mathrm{pH} 7.4 \pm 0.2$ ) and tryptic soy agar (TSA; tryptone $15 \mathrm{~g}$, soy peptone $5 \mathrm{~g}, \mathrm{NaCl} 5 \mathrm{~g}$, and agar $15 \mathrm{~g}$ per liter, $\mathrm{pH} 7.3 \pm 0.2$ ) media. The plates were incubated at $30^{\circ} \mathrm{C}$ for $2-3 \mathrm{~d}$. After colonies appeared, all the isolates were purified and preserved as glycerol stock at $-80^{\circ} \mathrm{C}$ for further use.

\subsection{Screening for Antagonistic Activity Against P. versicolor XJ27}

Antagonistic potentials of rhizospheric isolates were investigated according to dual culture assay, as described by Zhao et al. [24], with some modifications. A small block of agar with fungal mycelia ( $5 \mathrm{~mm}$ diameter) was cut from the actively growing edge of a freshly cultured plate and kept at the center of a newly prepared PDA plate. Bacterial isolates were cultivated in Luria-Bertani (LB) broth (yeast extract $5 \mathrm{~g}$, tryptone $10 \mathrm{~g}$, and $\mathrm{NaCl} 10 \mathrm{~g}$ per liter, $\mathrm{pH} 7.2 \pm 0.2$ ) at $30^{\circ} \mathrm{C}$ for $48 \mathrm{~h}$. The isolates ( $2 \mu \mathrm{L}$ were spot-inoculated with approximately $10^{8} \mathrm{CFU} / \mathrm{mL}$ at $25 \mathrm{~mm}$ distance from the fungal block. Negative control was maintained using only the fungal block at the center, and LB broth $(2 \mu \mathrm{L}$ was spot-inoculated instead of bacteria. After incubating the plates at $28^{\circ} \mathrm{C}$ for $9 \mathrm{~d}$, the inhibition zone was calculated according to Mukta et al. [25], following this equation.

$$
\text { The growth inhibition }(\%)=(X-Y) / X \times 100
$$

where $X=$ mycelial diameter of fungus in the absence of antagonistic bacteria; $Y=$ mycelial diameter of fungus in the presence of antagonistic bacteria. For each treatment, four replications were used and the experiment was conducted three times.

\subsection{Identification of Potential Antagonistic Bacteria}

The rhizospheric bacteria with antagonistic potentials were selected for molecular identification. The isolates were identified by $16 \mathrm{~S}$ rRNA gene sequencing. The $16 \mathrm{~S}$ rRNA gene was amplified by using primers 27F (5-AGAGTTTGATCCTGGCTCAG-3') and 1492R (5-GGTTACCTTGTTACGACT-3') [26] . Polymerase chain reaction (PCR) was performed with a volume of $50 \mu 12 \times$ TSINGKE Master Mix (TsingKe Biological Technology, Beijing, China. The PCR conditions were as follows: $98^{\circ} \mathrm{C}$ for $5 \mathrm{~min}, 30$ cycles for denaturation at $98^{\circ} \mathrm{C}$ for $10 \mathrm{~s}$, annealing at $53{ }^{\circ} \mathrm{C}$ for $10 \mathrm{~s}$, elongation at $72{ }^{\circ} \mathrm{C}$ for $15 \mathrm{~s}$, and final run at $72{ }^{\circ} \mathrm{C}$ for $3 \mathrm{~min}$. The PCR products were electrophoresed in $1 \%(w / v)$ agarose gel to see the amplified bands. Then, the PCR products were sent to TsingKe Biological Technology for sequencing. The resulted sequences were analyzed using BLAST [27], and closest strains were determined depending on sequence similarity. The nucleotide sequences were aligned by 
CLASTALW [28], and phylogenetic trees were made by the maximum likelihood method using the MEGA 5.0 program [29].

\subsection{Antagonistic Efficacy of Extracellular Culture Filtrates and Their Thermal Stability Assay}

Antifungal actions and thermal stability of extracellular culture filtrates of B. siamensis S3 and B. tequilensis $\mathrm{S} 5$ were tested by measuring the mycelial growth inhibition of $P$. versicolor $\mathrm{XJ} 27$ on PDA plates, according to Ohike et al. [30]. Two strains were grown in $250 \mathrm{~mL}$ Erlenmeyer flasks containing $100 \mathrm{~mL}$ of LB media at $30^{\circ} \mathrm{C}$ for $48 \mathrm{~h}$. The extracellular filtrate was taken by centrifugation at $16,000 \times g$ at $24^{\circ} \mathrm{C}$ for $10 \mathrm{~min}$, followed by sterilization using a $0.22-\mu \mathrm{m}$ pore diameter filter. Sterilized extracellular filtrates were mixed with PDA $(10 \% v / v)$. After mixing, $10 \mathrm{~mL}$ of aliquots were poured into Petri plates. For the control, sterilized LB media was mixed with PDA in place of extracellular filtrates. At the center of each plate, a 5-mm fungal block was placed and kept at $28^{\circ} \mathrm{C}$ for incubation. After $9 \mathrm{~d}$ of incubation, the inhibition zone was calculated, followed by the abovementioned techniques. For testing thermal stability, extracellular filtrates were autoclaved at $121^{\circ} \mathrm{C}$ for $20 \mathrm{~min}$ and were used against pathogens. Furthermore, the culture filtrate was stored at $4{ }^{\circ} \mathrm{C}$ for $72 \mathrm{~h}$ and inoculated against the fungus. The plates were prepared in similar methods. The experiment was performed three times, with three replications for each treatment.

\subsection{Hyphal Structures Observation Using SEM and TEM}

A fungal block was taken from the point of inhibition caused by S3, which was the most potentially antagonistic bacteria, and observed by scanning/transmission (SEM/TEM) electron microscopy, according to Gao et al. [31]. A mycelial block of $7 \mathrm{~mm}$ was picked up from the S3-treated PDA plate and from the control plate in which only P. versicolor XJ27 was grown. The mycelial plugs were washed twice with PBS and fixed in glutaraldehyde [2.5\% $(v / v)$ in $0.1 \mathrm{M}$ PBS] for $3 \mathrm{~h}$ at room temperature. The specimens were postfixed in osmium tetroxide [ $1 \%(w / v)$ in $0.1 \mathrm{M} \mathrm{PBS}]$ for $1 \mathrm{~h}$ at room temperature. The specimens were dehydrated in a graded series of ethanol concentrations (30-100\%) until the fungal samples were fully dry. Then, the hyphal morphological observation of $P$. versicolor XJ27 was made using SEM (TM-1000, Hitachi, Japan) and TEM (JEM-1230, JEOL, Akishima, Japan).

\subsection{Hydrolytic Enzymes Activity Assay}

The chitinase activity test was conducted by using nutrient agar media added with $1 \%$ colloidal chitin [32]. For protease activity, a minimal medium supplemented with casein $(1 \%, w / v)$ was used for bacterial spot inoculation [33]. $\beta-1,3-$ Glucanase activity was tested by inoculating bacteria on an aniline blue pachyman (ABP) agar plate [34]. Escherichia coli DH5 $\alpha$ was used as a negative control for the hydrolytic enzyme activity assay.

\subsection{Detection of Lipopeptides in Antagonistic Bacteria by MALDI-TOF-MS Analysis}

For lipopeptides detection, the two strains with the most potential (S3 and S5) were analyzed by matrix-assisted laser desorption ionization-time of flight mass spectrometry (MALDI-TOF-MS). The lipopeptides' characterization was done on dried-droplet intact whole cells of the rhizospheric bacteria, as described by Masum et al. [35]. Antagonistic bacteria were grown on LB agar plates at $30{ }^{\circ} \mathrm{C}$ for $48 \mathrm{~h}$ and individual colonies were carefully suspended in an Eppendorf tube containing a matrix solution (10 mg per $\mathrm{ml}$ cyano-4-hydroxycinnamic acid in $70 \%$ water, $30 \%$ acetonitrile, and $0.1 \%$ TFA). Then, $1 \mu \mathrm{l}$ of the homogenized sample solution was spotted onto a MALDI-TOF MTP 384 target plate (Bruker Daltonik GmbH, Leipzig, Germany). After natural drying, MALDI-TOF-mass spectra were recorded using an ultra-extreme instrument MALDI-TOF (Bruker, Bremen, Germany) equipped with a smart beam laser. Spectral data were observed for the presence of lipopeptides in the rhizospheric antagonistic bacteria. 


\subsection{Antagonistic Assay on Detached Leaf Against P. versicolor XJ27}

A detached leaf assay was conducted using healthy bayberry leaves, according to Li et al. [8]. In brief, healthy bayberry leaves were sterilized with $5 \% \mathrm{NaClO}$ for $1 \mathrm{~min}$, followed by repeated rinsing with $\mathrm{ddH}_{2} \mathrm{O}$. A cross mark was made at the back of leaves with a sterilized needle. Then, $20 \mu \mathrm{l}$ of cell suspension of antagonistic bacteria (approximately $10^{8} \mathrm{CFU} / \mathrm{mL}$ ) or extracellular culture filtrate was poured at the center of the cross mark and allowed two hours for absorption by the leaves. A similar amount of fungicide, namely, Prochloraz, was applied at the concentration of $4.25 \mathrm{mg} / \mathrm{L}$ as another treatment [8]. A mycelial plug of $5 \mathrm{~mm}$ was taken from four-day-cultured P. versicolor XJ27 on a PDA plate and put at the center of the cross mark (facing downward) that had been previously inoculated with antagonistic bacteria or extracellular culture filtrates. A sterile PDA plug without mycelia was used as a negative control. For positive control, a PDA plug with fungal mycelium was inoculated on a leaf without bacterial culture suspension or culture filtrate. The inoculated leaves were kept on sterile moistened filter papers in $15-\mathrm{cm}$ diameter Petri dishes and kept at $28^{\circ} \mathrm{C}$ for $7 \mathrm{~d}$ in a growth chamber. A $16 \mathrm{~h}$ LED light condition, with a light intensity of $212.75 \mu \mathrm{mol} \mathrm{m}^{-2} \mathrm{~s}^{-1}$ and $75 \%$ humidity, was maintained during this period. The size of the lesions was measured and recorded to calculate the percentage of inhibition relative to the control. The experiment was conducted with three replications for each treatment and conducted three times.

\subsection{Statistical Analysis}

Data were analyzed by one-way analysis of variance following posthoc multiple comparisons using SPSS 16.0 software (SPSS Inc. South Wacker Drive, Chicago, IL, USA). The treatments were separated by the least significant difference test.

\section{Results}

\subsection{Rhizospheric Bacteria Showed XJ27 Inhibition In Vitro}

The rhizospheric bacterial strains were tested for their antifungal actions against $P$. versicolor $\mathrm{XJ} 27$ by dual culture assay; 10 isolates showed significant mycelial growth inhibition of the fungal pathogen (Figure 1). The mycelial inhibition ranged from $64.0 \%$ to $82.9 \%$. The S3 and S5 strains showed comparatively higher activity than other isolates. Based upon the in vitro performance, the two isolates S3 and S5 were selected for further study.

\subsection{Antagonistic Bacteria were Identified as Bacillus}

Ten rhizospheric isolates with antifungal activity were subjected to identification by $16 \mathrm{~S}$ rRNA analysis. Homology analyses were done by submitting nucleotide sequences derived from PCR-amplified 16S rRNA fragments to the EzBioCloud database service (www.ezbiocloud.net). The sequences of eight isolates (S1, S4, S5, S6, S7, S8, S9, and S10) had up to $99.9 \%$ homology with B. tequilensis, and two isolates (S2 andS3) had up to $99.9 \%$ homology with B. siamensis. The accession numbers from MW024076 to MW024085 were obtained by submitting the 16S rRNA gene sequences to NCBI GenBank. A brief description is given in Table S1 for all identified isolates. The phylogenetic tree was constructed using the $16 \mathrm{~S}$ rRNA sequences, which showed that $\mathrm{S} 3$ was in the group of $B$. siamensis and $\mathrm{S} 5$ was in the group of B. tequilensis (Figure 2).

\subsection{Extracellular Culture Filtrates Showed Antifungal Activity and Thermal Stability}

The extracellular filtrate of antagonistic bacteria showed significant mycelial growth inhibition against P. versicolor XJ27 (Figure 3). The normal culture filtrates of S3 and S5 inhibited $87.7 \%$ and $75.3 \%$ of fungal growth, respectively (Figure 3A). Their autoclaved culture filtrates also showed inhibition against that fungal pathogen of $85.3 \%$ and $81.8 \%$ by S3 and S5, respectively (Figure 3B). The culture filtrate was stored at $4{ }^{\circ} \mathrm{C}$, and the S3 and S5 showed $85.2 \%$ and $81.0 \%$ inhibition. 

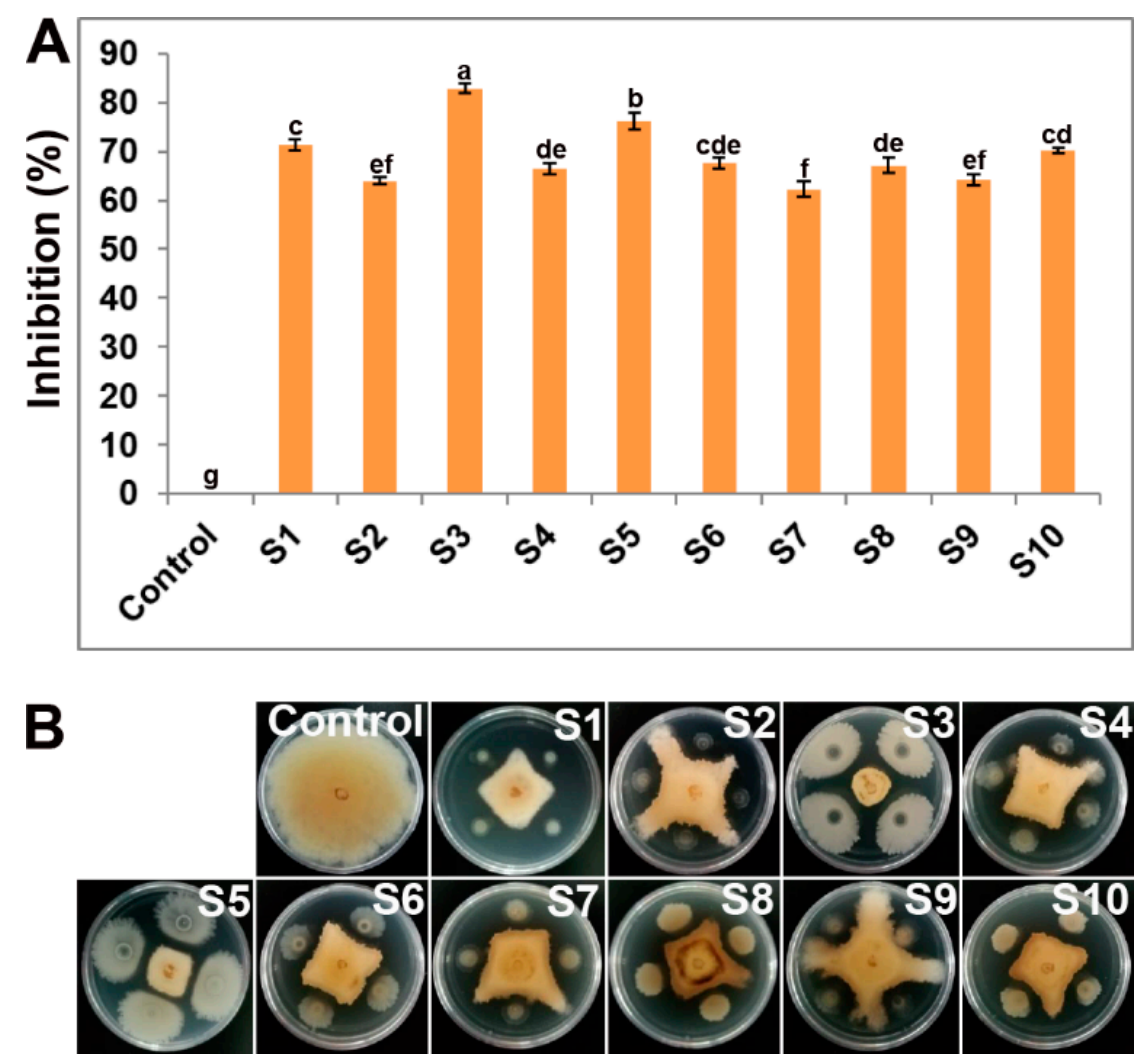

Figure 1. Antifungal assay of rhizospheric soil bacteria of sweet potato fields against $P$. versicolor XJ27. (A) Inhibitory effects of ten isolates of rhizospheric soil bacteria on the mycelial growth of $P$. versicolor XJ27 relative to control. (B) Dual culture assay on potato dextrose agar (PDA) plate with antagonistic bacteria and P. versicolor XJ27. For the control, the fungus was inoculated at the center and LB broth was point-inoculated instead of antagonistic bacteria. Inhibition (\%) was calculated in comparison to control. Values are means \pm SE of four replications for each treatment. Similar letters are not different at $p \leq 0.05$.

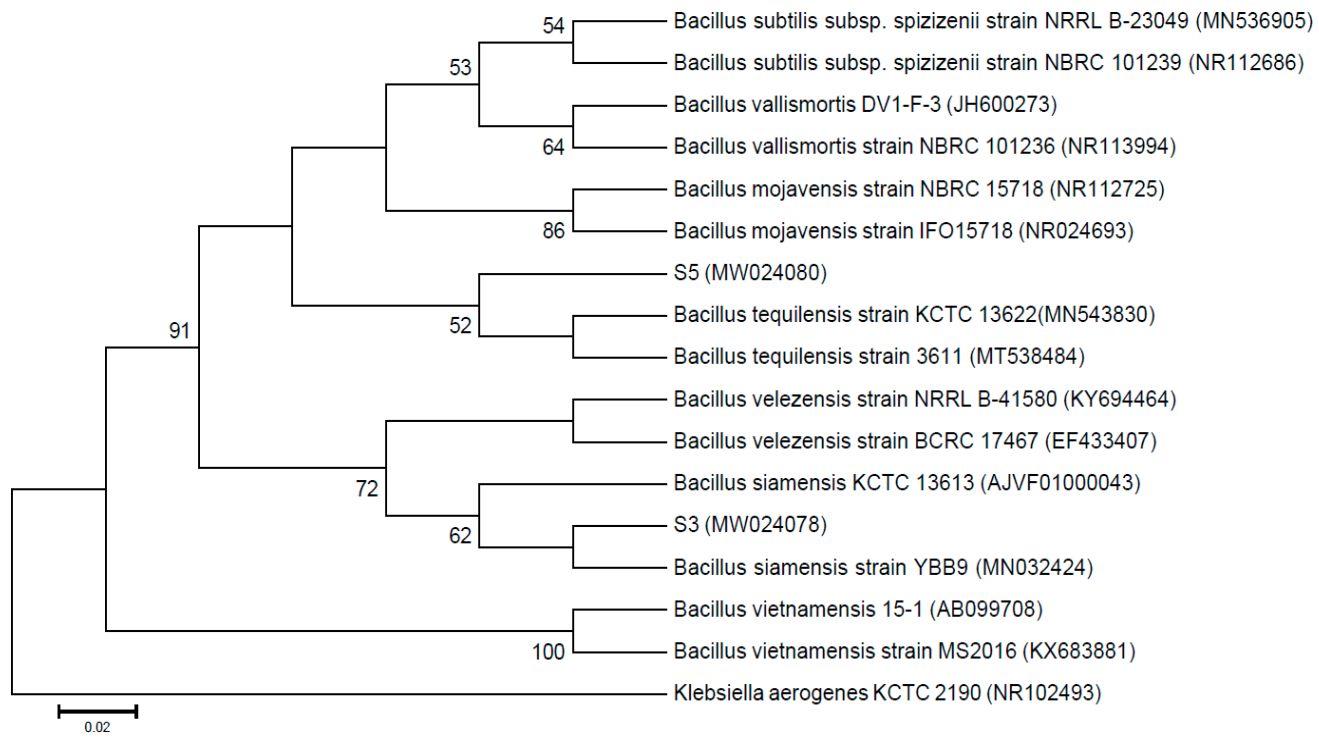

Figure 2. Phylogenetic tree constructed by the maximum likelihood method based upon the alignment of partial 16S rRNA gene sequences of antagonistic bacteria. Bootstrap analysis (1000 replicates) for node values more than $50 \%$ is shown. The scale bar indicates the number of substitutions per site. 


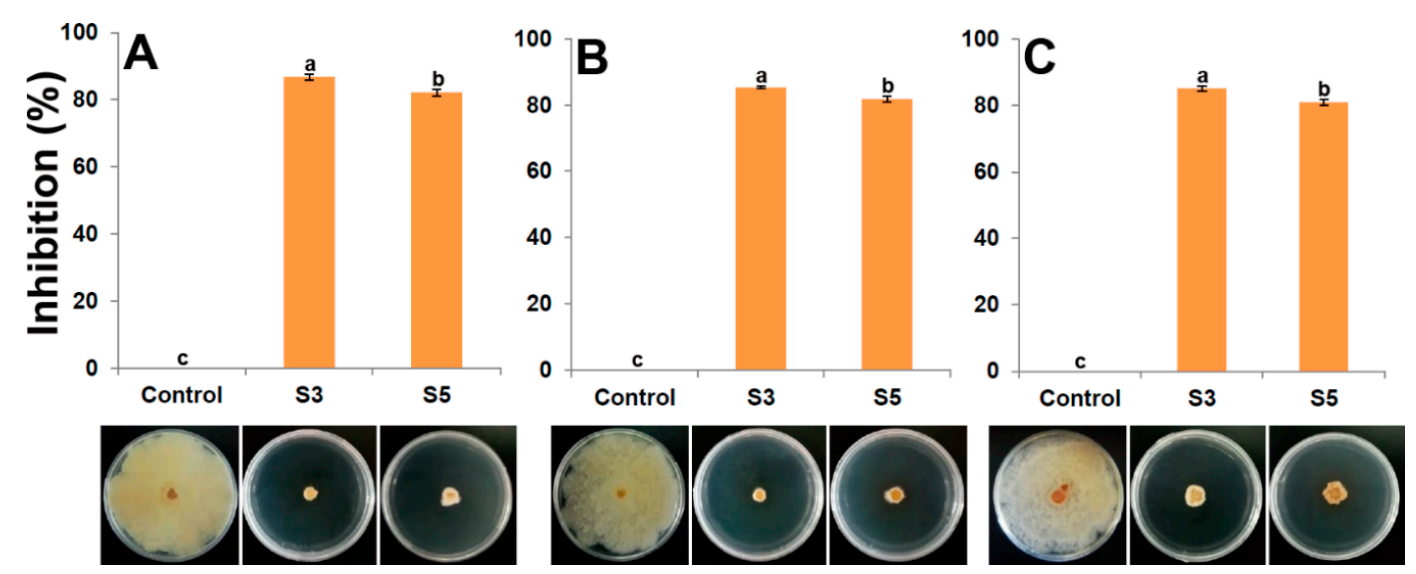

Figure 3. Antifungal action of extracellular culture filtrates. (A) Inhibition by normal extracellular culture filtrate. (B) Inhibition by autoclaved extracellular culture filtrate. (C) Inhibition by extracellular culture filtrate stored at $4{ }^{\circ} \mathrm{C}$ for $72 \mathrm{~h}$. For the control, sterilized LB media was added with PDA instead of extracellular culture filtrates. Data are mean value $\pm \mathrm{SE}$ of three replications for each treatment. The same letters are not significantly different at $p \leq 0.05$.

\subsection{Damaged Hyphal Structures Were Observed by SEM and TEM}

Microscopic observation indicated that S3 could alter the hyphal morphology of P. versicolor XJ27 (Figure 4). SEM imaging showed that S3-treated hyphae was damaged, twisted, and broken in contrast to normal well-defined hyphae in control (Figure 4A,B). TEM imaging revealed that the bacterial treatment caused leakage, thinning of the cell wall, and loss of cell contents, but in control, the cell walls had normal thickness and contained organelles (Figure 4C,D).

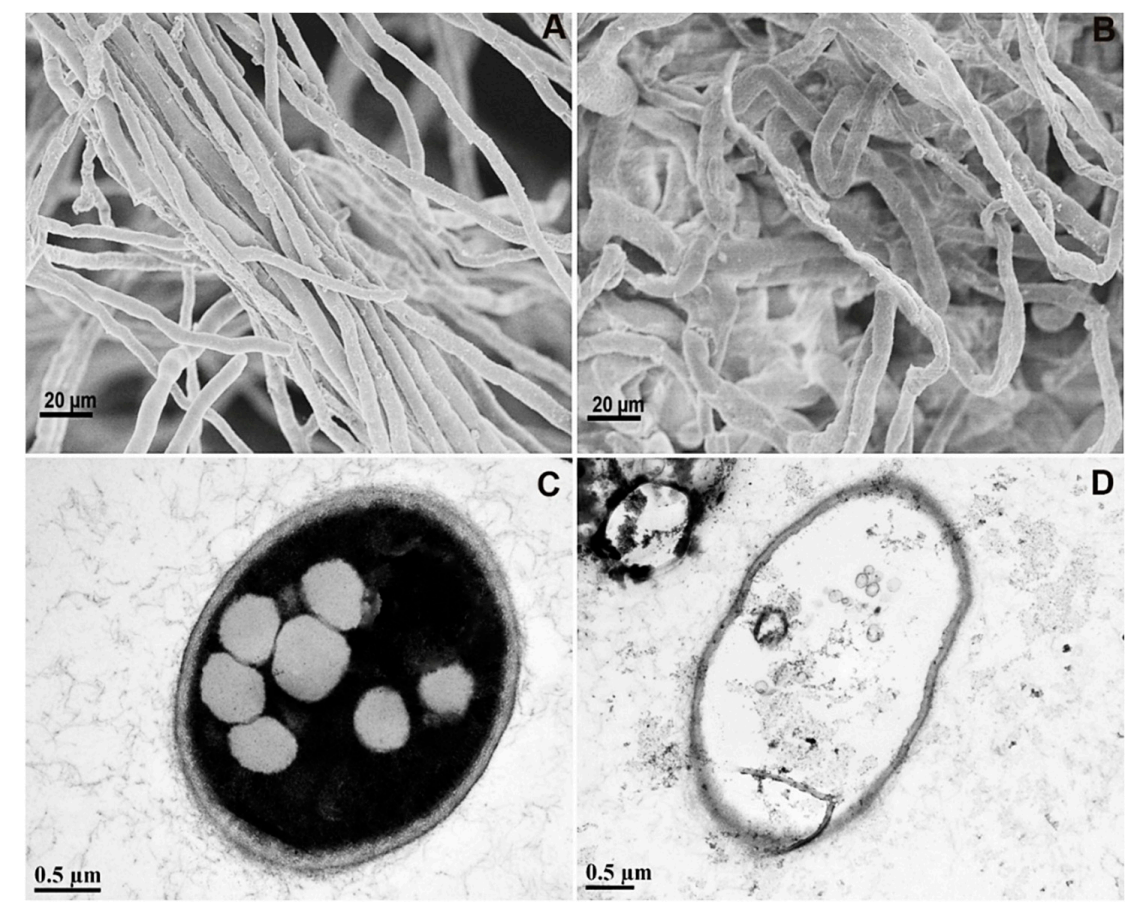

Figure 4. SEM and TEM for hyphal structure observation. SEM of normal hyphae without treatment in control (A); deformed, twisted, and abnormal hyphae treated by S3 (B); TEM of cross-section of normal hypha, with thick, intact cell wall and organelles in control (C); thin cell wall with leakage and loss of internal cell contents in treated hypha (D). 


\subsection{Hydrolytic Enzymes Activity Assay}

The hydrolytic enzymes activity assay results indicated that both S3 and S5 can produce chitinase and protease (Figure 5). Both strains did not show $\beta$-1, 3-Glucanase activity.

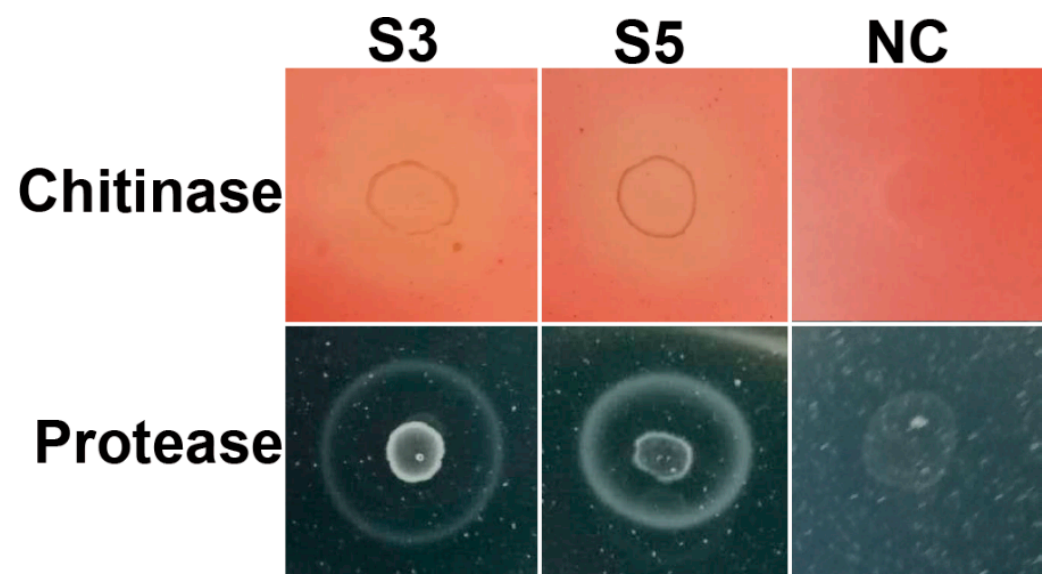

Figure 5. Hydrolytic enzymes activity assay. E. coli DH5 $\alpha$ was used as negative control (NC).

\subsection{Lipopeptides were Detected in S3 and S5}

MALTI-DOF mass spectrometry results showed a series of mass spectra in both S3 and S5 strains (Figure 6). The major mass peaks obtained from S3 ranged from m/z 1000 to 1260 (Figure 6A); the range of $\mathrm{m} / \mathrm{z} 1000$ to 1151 belongs to surfactin, iturin, and mycosubtilin. The last peaks (m/z 1205 to 1260) are in the range of the polymyxin family, generally found in Paenibacillus [36,37]. The intensities of iturin are higher than that of surfactin. The known major lipopeptides produced by the Bacillus are in a range of $\mathrm{m} / \mathrm{z} 800$ to 1600 [38-41]. The mass peaks of S5 are in a range of m/z 965 to 1721 (Figure 6B and Figure S1). The mass peaks from 1000 to 1151 are in the families of surfactin, iturin, and mycosubtilin. The values from m/z 1280 to 1340 are in the polymyxin family and m/z 1450 to 1530 in the fengycin family. The mass peak for $\mathrm{m} / \mathrm{z} 968$ comes under the fusaricidin family [36]. The detailed assignments of mass peaks for known lipopeptides are given in Table 1.

Table 1. Lipopeptides detected in antagonistic bacteria by MALTI-DOF-MS analysis.

\begin{tabular}{|c|c|c|}
\hline Observed Mass Peaks (m/z) & Lipopeptides & References \\
\hline \multicolumn{3}{|l|}{ Strain: S3 } \\
\hline 1023.627 & Leu/Ile-7 C15 Surfactin, $[\mathrm{M}+\mathrm{H}]^{+}$ & [41] \\
\hline 1039.599 & C15 Surfactin, $\left[\mathrm{M}+\mathrm{Na}-\mathrm{H}_{2} \mathrm{O}\right]^{+}$ & [42] \\
\hline 1058.783 & C15 Surfactin, $[\mathrm{M}+\mathrm{Na}]^{+}$ & [43] \\
\hline 1065.658 & C14 Iturin, $[\mathrm{M}+\mathrm{Na}]^{+}$ & [43] \\
\hline 1074.755 & C15 Surfactin, $[\mathrm{M}+\mathrm{K}]^{+}$ & [44] \\
\hline 1079.677 & C15 Iturin, $[\mathrm{M}+\mathrm{Na}]^{+}$ & [43] \\
\hline 1095.657 & C15 Iturin, $[\mathrm{M}+\mathrm{K}]^{+}$ & [43] \\
\hline 1100.731 & C18 Iturin, $[\mathrm{M}+\mathrm{H}]^{+}$ & [45] \\
\hline 1109.679 & C16 Iturin, $[\mathrm{M}+\mathrm{K}]^{+}$ & [46] \\
\hline 1122.707 & C17 Iturin, $[\mathrm{M}+\mathrm{K}]^{+}$ & [38] \\
\hline 1138.679 & C18 Mycosubtilin, $[\mathrm{M}+\mathrm{K}]^{+}$ & [47] \\
\hline 1151.747 & C19 Mycosubtilin, $[\mathrm{M}+\mathrm{K}]^{+}$ & [47] \\
\hline 1257.823 & Polymyxin B6, $[\mathrm{M}+\mathrm{K}]^{+}$ & [41] \\
\hline \multicolumn{3}{|l|}{ Strain: S5 } \\
\hline 1030.805 & C13 Surfactin, $[\mathrm{M}+\mathrm{Na}]^{+}$ & [43] \\
\hline 1044.823 & C14 Surfactin, $[\mathrm{M}+\mathrm{Na}]^{+}$ & [43] \\
\hline 1058.845 & C15 Surfactin, $[\mathrm{M}+\mathrm{Na}]^{+}$ & [43] \\
\hline 1074.816 & C15 Surfactin, $[\mathrm{M}+\mathrm{K}]^{+}$ & [44] \\
\hline 1100.785 & C18 Iturin, $[\mathrm{M}+\mathrm{H}]^{+}$ & [45] \\
\hline 1122.808 & C17 Iturin, $[\mathrm{M}+\mathrm{K}]^{+}$ & [38] \\
\hline 1151.807 & C19 Mycosubtilin $[\mathrm{M}+\mathrm{K}]^{+}$ & [47] \\
\hline
\end{tabular}



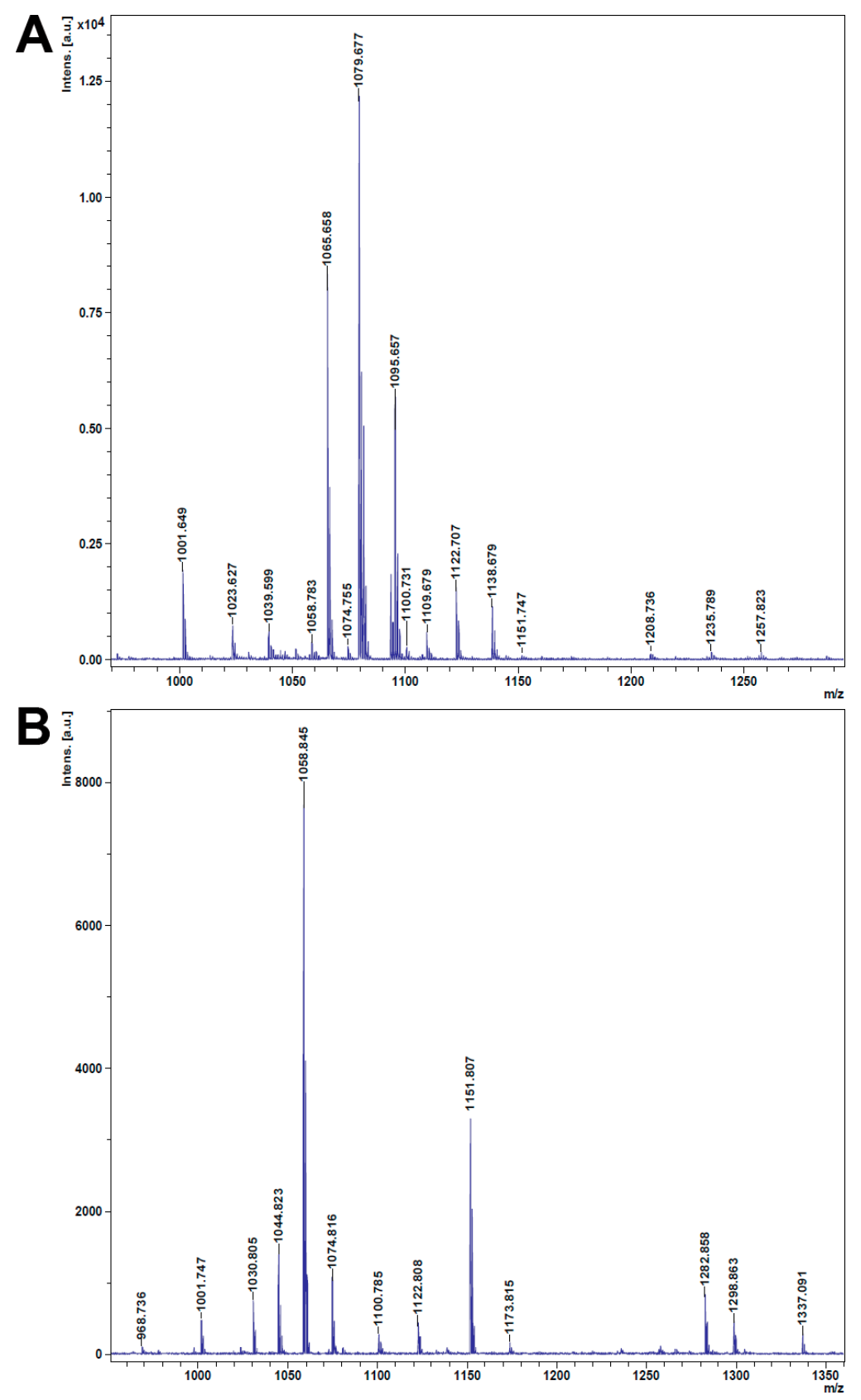

Figure 6. Lipopeptides detection through MALDI-TOF mass spectrometry analysis. (A) Mass spectra obtained from S3; (B) mass spectra obtained from S5.

\subsection{Inhibition of P. versicolor XJ27 on Bayberry Leaves}

Following the satisfactory fungal inhibition by antagonistic bacteria and their extracellular culture filtrates, inhibition against $P$. versicolor $\mathrm{XJ} 27$ was observed on bayberry leaves (Figure 7). The detached leaf assay results showed that S3 and S5 inhibited leaf lesion by $76.1 \%$ and $74.2 \%$, respectively. The extracellular culture filtrates of S3 and S5 inhibited leaf lesion by $82.3 \%$ and $76.2 \%$, respectively. Prochloraz inhibited $53.1 \%$ of lesions. This result suggests that these antagonistic bacteria can be used as an environmentally safe alternative to fungicides. 


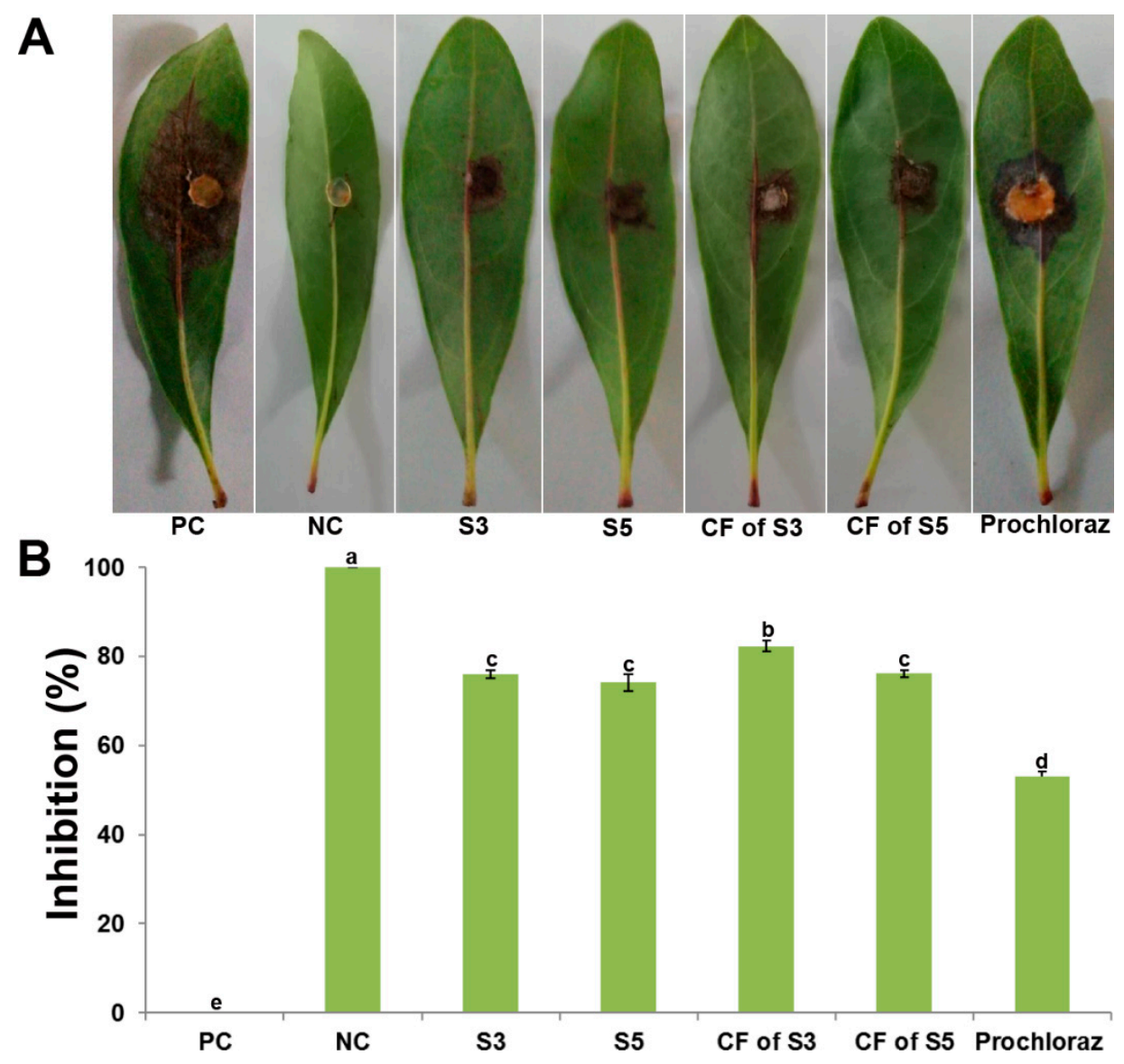

Figure 7. Detached leaf assay for antifungal activity. (A) Effects of antagonistic bacteria and their extracellular culture filtrate on bayberry leaves against P. versicolor XJ27. (B) Disease inhibition (\%) relative to positive control. Data are mean $\pm \mathrm{SE}$ of three replications for each treatment. Same letters are not significantly different at $p \leq 0.05$. For positive control (PC), only the fungal mycelial plug was inoculated. For negative control (NC), a sterile PDA plug without mycelia was used. CF, extracellular culture filtrate. Prochloraz denotes fungicide.

\section{Discussion}

Several species of Pestalotiopsis genus cause the twig blight of bayberry plants, a source of economic loss to farmers $[7,8,12]$. Fungicides are primarily being used for controlling bayberry twig blight pathogens. Conversely, rhizospheric bacteria are potential tools for the biological control of plant pathogens, as well as for plant growth promotion [48]. However, suitable in-vitro research is essential to isolate and screen the promising indigenous strains. The rhizospheric zone has a very complex dynamic, where numerous biogeochemical processes happened via various physical activities, and diverse chemicals are released by plant roots and mediated by soil microbes. Plant root exudates are continuously released into the rhizosphere. Root exudates play key roles in enriching the rhizosphere with specific microbial populations [49,50].

Rhizospheric bacteria isolated from sweet potato fields were screened against $P$. versicolor XJ27, which causes twig blight of bayberry. Among them, ten bacterial isolates showed reasonable fungal inhibition. Molecular identification indicated that all sweet potato rhizospheric antagonistic bacteria belonged to the Bacillus genus; eight strains were closest to $B$. tequilensis and two strains were closest to B. siamensis. Two strains (S3 and S5) exhibited the highest fungal inhibition in dual culture plates. Phylogenetic analysis showed that $\mathrm{S} 3$ is closely related to B. siamensis and S5 to B. tequilensis. These strains were selected for further analysis to explore the fungal inhibition mechanisms. 
The bacteria from the genus Bacillus are recognized as safe microbes and have the potential ability to synthesize a broad spectrum of useful compounds for agronomic and industrial uses [51]. They produce endospores that can support the survival of Bacillus under various environmental stresses, long-time storage ability, and easy preparation of suitable formulations [52]. Many soil-inhabiting bacilli bacteria can exist as endophytes or epiphytes [53] and may support plant protection against phytopathogenic infection by blending various modes of action [54-56]. These attributes have led to the increased possibility of using the Bacillus species and/or their secondary metabolites as useful tools for plant pathogen control instead of chemicals [57-59].

The strains S3 and S5 strongly inhibited fungal growth in dual culture plates against $P$. versicolor $\mathrm{XJ} 27$. The preliminary inhibition results paid attention to the production of antifungal compounds in vitro by both strains. It is well recognized that bacteria generally produce cell wall hydrolytic enzymes and secondary metabolites to constrain pathogenic growth [60]. In this study, both strains produced several cell wall hydrolytic enzymes as well as lipopeptides. With these cell-wall-degrading enzymes, together with natural antifungal substances, many species of Bacillus can inhibit phytopathogenic fungi [60]. Chitinase and protease may cause a hyphal abnormality of fungal pathogens [61,62]. The chitinase and protease activity was observed in several species of Bacillus [63-65]. Therefore, S3 and S5 can produce chitinase and protease and might cause the hyphal damage and ultimate growth inhibition of $P$. versicolor $\mathrm{XJ} 27$.

The lipopeptides are a group of secondary metabolites with comparatively low molecular weight; they are nonribosomal peptides. These are amphiphilic in nature and engage attention for their surfactant and antimicrobial activities. Bacillus has been known to utilize these lipopeptides in the protection of plants, either directly harnessing the phytopathogenic fungi or helping to induce the systemic resistance of host plants [59,66-68]. The S3 and S5 strains produced lipopeptides, mainly surfactin, iturin, and mycosubtilin. The mass spectrometry analysis of S3 showed more mass peaks of lipopeptides, with higher intensity than S5. This result is consistent with the phenotype of fungal inhibition because S3 inhibited more fungal growth than S5.

Surfactin produced by Bacillus showed strong antifungal activity against Fusarium moniliforme, F. oxysporum, F. solani, Trichoderma reesei, and T. atroviride [42,69]. The surfactin of Bacillus subtilis caused mycelium projection, cell damage, and protein and nucleic acid leakage of $F$. moniliforme [69]. Iturin A produced by B. amyloliquefaciens caused damage to cell walls as well as cell membranes, allowing the leakage of internal cell contents in the treated F. graminearum [70]. Mycosubtilin synthesized by B. subtilis showed biocontrol activity against Pythium infection in tomato seedlings [71]. In our study, the SEM and TEM results suggested the ultrastructural alteration of $P$. versicolor XJ27 hyphae treated with S3. The treated hyphae were damaged, twisted, and broken, while normal hyphae were observed in control. Furthermore, damaged cell walls and cell membranes allowed the leakage of internal cell contents. SEM and TEM micrographs showed severe damage to cell walls and cell membranes of Fusarium spp. treated by iturin A and the surfactin of Bacillus $[69,70]$. Therefore, both the hydrolytic enzymes and lipopeptides might cause such types of damage to fungal structures. We can conclude thesetypes of damage are the basis for the significant inhibition of $P$. versicolor XJ27.

The extracellular culture filtrates obtained from S3 and S5 also showed significant inhibition of the target fungal pathogen. The filtrates obtained from both strains continued their antifungal activity after thermal treatment by autoclaving and were also active after storing the culture filtrate at $4{ }^{\circ} \mathrm{C}$. Ohike et al. [30] observed that a 10\% culture filtrate of Bacillus sp. KL1 inhibited $80 \%$ growth of Rhizoctonia solani on a PDA plate. Some Bacillus produce antibiotics with a wide array of antimicrobial actions at various temperatures and $\mathrm{pH}$ conditions. The substances are secondary metabolites called cyclic lipopeptides with amphipathic natures, such as surfactin, iturin, and fengycin [72,73]. The antagonistic bacteria S3 and S5, as well as their extracellular culture filtrates, showed significant inhibition of $P$. versicolor XJ27 on bayberry leaves compared to the fungicide Prochloraz. The sterilized culture filtrates and culture suspension of $B$. tequilensis GYLH001 significantly inhibited the lesion length caused by M. oryzae on detached rice leaves [64]. 
To check adoptive capability, the culture suspension or extracellular culture filtrate of antagonistic bacteria should be applied to the bayberry plants in orchards. It should be checked if these biocontrol agents can retain their activity under various abiotic (such as sunlight, rain) and biotic (such as the microbial community of the host plant) factors. After that, a suitable application frequency of biocontrol agents should be determined in comparison with the fungicides commonly used by the farmers. Then, these strains can be utilized in biocontrol programs for bayberry twig blight fungi. Furthermore, these strains can also be tested against other phytopathogenic fungi as well.

\section{Conclusions}

The overall results suggest that B. siamensis S3 and B. tequilensis S5 have antifungal potential against $P$. versicolor $\mathrm{XJ} 27$. Both strains possessed the necessary attributes of biocontrol agents, such as hydrolytic enzymes and lipopeptides. If the suitability and effects of bacterial suspension or extracellular culture filtrate application can be achieved under field conditions, these bacteria can be recommended as biocontrol agents against the twig blight pathogens of bayberry. Therefore, additional study is required for their fruitful application in biocontrol programs at the field level.

Supplementary Materials: The following are available online at http://www.mdpi.com/2073-4395/10/11/1811/s1, Figure S1: Mass spectra of lipopeptides obtained from S5 through MALDI-TOF mass spectrometry analysis, Table S1: A brief description of identified antagonistic bacteria isolated from rhizospheric soil.

Author Contributions: Conceptualization, M.A.A., H.R., T.A., and B.L.; methodology, M.A.A., H.R., J.L., and T.A.; software, M.A.A. and J.L.; investigation, M.A.A., H.R., J.L., and T.A; supervision, X.Q., Q.A., and B.L.; writing - original draft preparation, M.A.A., H.R., and T.A.; writing-review and editing, all the authors contribute to this part. All authors have read and agreed to the published version of the manuscript.

Funding: This work was supported by the Zhejiang Provincial Project (2020C02001, 2017C02002, 2019C02006, 2020C02006), the National Natural Science Foundation of China (31872017, 32072472, 31571971, 31371904, 31801787, 31901925), the Zhejiang Provincial Natural Science Foundation of China (LZ19C140002,GN18C140001), the National Key Research and Development Program of China (2017YFD0201104; 2018YFD0300900), the Shanghai Agriculture Applied Technology Development Program (2019-02-08-00-08-F01150), the Key Scientific Technological Project of Ningbo (2016C11017), Fundamental Research Funds for the Central Universities, Dabeinong Funds for Discipline Development and Talent Training in Zhejiang University, and the Key Subject Construction Program of Zhejiang for Modern Agricultural Biotechnology and Crop Disease Control.

Conflicts of Interest: The authors declare no conflict of interest.

\section{References}

1. Chen, K.; Xu, C.; Zhang, B.; Ferguson, I.B. Red bayberry: Botany and horticulture. Hortic. Rev. 2004, 30, 83-114.

2. Shi, L.; Cao, S.; Chen, X.; Chen, W.; Zheng, Y.; Yang, Z. Proanthocyanidin Synthesis in Chinese Bayberry (Myrica rubra Sieb. Et Zucc.) Fruits. Front. Plant. Sci. 2018, 9, 212. [CrossRef] [PubMed]

3. Li, Z.L.; Zhang, S.L.; Chen, D.M. Red bayberry (Myrica rubra Seib \& Zucc.): A valuable evergreen tree fruit for tropical and subtropical areas. Acta Hortic. 1992, 321, 112-121.

4. Bao, J.; Cai, Y.; Sun, M.; Wang, G.; Corke, H. Anthocyanins, flavonols, and free radical scavenging activity of Chinese bayberry (Myrica rubra) extracts and their color properties and stability. J. Agric. Food Chem. 2005, 53, 2327-2332. [CrossRef]

5. Fang, Z.; Zhang, M.; Tao, G.; Sun, Y.; Sun, J. Chemical Composition of Clarified Bayberry (Myrica rubra Sieb. Et Zucc.) Juice Sediment. J. Agric. Food Chem. 2006, 54, 7710-7716. [CrossRef]

6. Chen, Y.F.; Lu, L.M.; Ni, H.Z.; Wang, Y.; Wang, Y.G.; Li, G.Q. First Report of Pestalotiopsis mangiferae and P. vismiae Causing Twig Dieback of Myrica rubra in China. Plant. Dis. 2012, 96, 588. [CrossRef]

7. Ren, -Y.H.; Li, G.; Qi, X.-J.; Fang, L.; Wang, H.-R.; Wei, J.-G.; Zhong, S. Identification and characterization of Pestalotiopsis spp. causing twig blight disease of bayberry (Myrica rubra Sieb. \& Zucc) in China. Eur. J. Plant. Pathol. 2013, 137, 451-461.

8. Li, W.; Hu, M.; Xue, Y.; Li, Z.; Zhang, Y.; Zheng, D.; Lu, G.; Wang, J.; Zhou, J. Five Fungal Pathogens Are Responsible for Bayberry Twig Blight and Fungicides Were Screened for Disease Control. Microorganisms 2020, 8, 689. [CrossRef] 
9. Nicolopoulou-Stamati, P.; Maipas, S.; Kotampasi, C.; Stamatis, P.; Hens, L. Chemical Pesticides and Human Health: The Urgent Need for a New Concept in Agriculture. Front. Public Health 2016, 4, 148. [CrossRef]

10. Cazorla, M.F.; Romero, D.; Pérez-García, A.; Lugtenberg, B.J.; Vicente, A.; Bloemberg, G. Isolation and characterization of antagonistic Bacillus subtilis strains from the avocado rhizoplane displaying biocontrol activity. J. Appl. Microbiol. 2007, 103, 1950-1959. [CrossRef]

11. Beneduzi, A.; Ambrosini, A.; Passaglia, L.M.P. Plant growth-promoting rhizobacteria (PGPR): Their potential as antagonists and biocontrol agents. Genet. Mol. Biol. 2012, 35, 1044-1051. [CrossRef] [PubMed]

12. Chen, Y.; Yan, F.; Chai, Y.; Liu, H.; Kolter, R.; Losick, R.; Guo, J.H. Biocontrol of tomato wilt disease by Bacillus subtilis isolates from natural environments depends on conserved genes mediating biofilm formation. Environ. Microbiol. 2013, 15, 848-864. [CrossRef] [PubMed]

13. Seleim, M.A.A.; Saead, F.A.; Abd-El-Mon, K.M.H.; Abo-ELyous, K.A.M. Biological control of bacterial wilt of tomato by plant growth promoting rhizobacteria. Plant. Pathol. J. 2011, 10, 146-153. [CrossRef]

14. Law, -F.J.W.; Ser, H.-L.; Khan, T.M.; Chuah, L.-H.; Pusparajah, P.; Chan, K.-G.; Goh, B.-H.; Lee, L.-H. The Potential of Streptomyces as Biocontrol Agents against the Rice Blast Fungus, Magnaporthe oryzae (Pyricularia oryzae). Front. Microbiol. 2017, 8, 3.

15. Compant, S.; Duffy, B.; Nowak, J.; Clément, C.; Barka, E.A. Use of plant growth-promoting bacteria for biocontrol of plant diseases: Principles, mechanisms of action, and future prospects. Appl. Environ. Microbiol. 2005, 71, 4951-4959. [CrossRef]

16. Khan, N.; Maymon, M.; Hirsch, A.M. Combating Fusarium Infection Using Bacillus-Based Antimicrobials. Microorganisms 2017, 5, 75. [CrossRef]

17. Khan, N.; Mishra, A.; Nautiyal, C.S. Paenibacillus lentimorbus B-30488r controls early blight disease in tomato by inducing host resistance associated gene expression and inhibiting Alternaria solani. Biol. Control 2012, 62, 65-74. [CrossRef]

18. Martínez-Hidalgo, P.; García, J.M.; Pozo, M.J. Induced systemic resistance against Botrytis cinerea by Micromonospora strains isolated from root nodules. Front. Microbiol. 2015, 6, 922. [CrossRef]

19. Khan, Z.; Doty, S.L. Characterization of bacterial endophytes of sweet potato plants. Plant. Soil 2009, 322, 197-207. [CrossRef]

20. Marques, M.J.; da Silva, T.F.; Vollu, R.E.; Blank, A.F.; Ding, G.C.; Seldin, L.; Smalla, K. Plant age and genotype affect the bacterial community composition in the tuber rhizosphere of field-grown sweet potato plants. FEMS Microbiol. Ecol. 2014, 88, 424-435. [CrossRef]

21. Marques, M.J.; da Silva, T.F.; Vollú, R.E.; de Lacerda, J.R.M.; Blank, A.F.; Smalla, K.; Seldin, L. Bacterial endophytes of sweet potato tuberous roots affected by the plant genotype and growth stage. Appl. Soil Ecol. 2015, 96, 273-281. [CrossRef]

22. Puri, R.; Dangi, S.; Dhungana, S.; Itoh, K. Diversity and Plant Growth Promoting Ability of Culturable Endophytic Bacteria in Nepalese Sweet Potato. Adv. Microbiol. 2018, 8, 734-761. [CrossRef]

23. Cui, H.; Yang, X.; Lu, D.; Jin, H.; Yan, Z.; Chen, J.; Li, X.; Qin, B. Isolation and characterization of bacteria from the rhizosphere and bulk soil of Stellera chamaejasme L. Can. J. Microbiol. 2015, 61, 171-181. [CrossRef] [PubMed]

24. Zhao, L.; Xu, Y.; Lai, X. Antagonistic endophytic bacteria associated with nodules of soybean (Glycine max L.) and plant growth-promoting properties. Braz. J. Microbiol. 2018, 49, 269-278. [CrossRef] [PubMed]

25. Mukta, J.A.; Rahman, M.; Sabir, A.A.; Gupta, D.R.; Surovy, M.Z.; Rahman, M.; Islam, M.T. Chitosan and plant probiotics application enhance growth and yield of strawberry. Biocatal. Agric. Biotechnol. 2017, 11, 9-18. [CrossRef]

26. Li, B.; Xu, L.H.; Lou, M.M.; Li, F.; Zhang, Y.D.; Xie, G.L. Isolation and characterization of antagonistic bacteria against bacterial leaf spot of Euphorbia pulcherrima. Lett. Appl. Microbiol. 2008, 46, 450-455. [CrossRef]

27. Altschul, F.S.; Gish, W.; Miller, W.; Myers, E.W.; Lipman, D.J. Basic local alignment search tool. J. Mol. Biol. 1990, 215, 403-410. [CrossRef]

28. Thompson, J.D.; Higgins, D.G.; Gibson, T.J. CLUSTAL W: Improving the sensitivity of progressive multiple sequence alignment through sequence weighting, position-specific gap penalties and weight matrix choice. Nucleic Acids Res. 1994, 22, 4673-4680. [CrossRef]

29. Tamura, K.; Peterson, D.; Peterson, N.; Stecher, G.; Nei, M.; Kumar, S. MEGA5: Molecular evolutionary genetics analysis using maximum likelihood, evolutionary distance, and maximum parsimony methods. Mol. Biol. Evol. 2011, 28, 2731-2739. [CrossRef] 
30. Ohike, T.; Makuni, K.; Okanami, M.; Ano, T. Screening of endophytic bacteria against fungal plant pathogens. J. Environ. Sci. 2013, 25, S122-S126. [CrossRef]

31. Gao, T.; Zhou, H.; Zhou, W.; Hu, L.; Chen, J.; Shi, Z. The Fungicidal Activity of Thymol against Fusarium graminearum via Inducing Lipid Peroxidation and Disrupting Ergosterol Biosynthesis. Molecules 2016, $21,770$. [CrossRef] [PubMed]

32. Krithika, S.; Chellaram, C. Isolation, Screening and Characterization of Chitinase producing Bacteriafrom marine wastes. Int. J. Pharm. Pharm. Sci. 2016, 8, 34-36.

33. Oberai, M.; Khanna, V. Mung Bean Rhizobacteria Antagonist to Fusarium oxysporum and Rhizoctonia solani. Acta Sci. Microbiol. 2019, 2, 82-90. [CrossRef]

34. Mahasneh, A.M.; Stewart, D.J. A Medium for detecting $\beta-(1 \rightarrow 3)$ Glucanase Activity in Bacteria. J. Appl. Bacteriol. 1980, 48, 457-458. [CrossRef]

35. Masum, I.M.M.; Liu, L.; Yang, M.; Hossain, M.M.; Siddiqa, M.M.; Supty, M.E.; Ogunyemi, S.O.; Hossain, A.; An, Q.; Li, B. Halotolerant bacteria belonging to operational group Bacillus amyloliquefaciens in biocontrol of the rice brown stripe pathogen Acidovorax oryzae. J. Appl. Microbiol. 2018, 125, 1852-1867. [CrossRef]

36. Vater, J.; Niu, B.; Dietel, K.; Borriss, R. Characterization of Novel Fusaricidins Produced by Paenibacillus polymyxa-M1 Using MALDI-TOF Ms Spectrometry. J. Am. Soc. Mass Spectrom. 2015, 26, 1548-1558. [CrossRef]

37. Vater, J.; Herfort, S.; Doellinger, J.; Weydmann, M.; Dietel, K.; Faetke, S.; Lasch, P. Fusaricidins from PaenibacilluspolymyxaM-1, a family of lipohexapeptides of unusual complexity-a mass spectrometric study. J. Mass Spectrom. 2017, 52, 7-15. [CrossRef]

38. Vater, J.; Kablitz, B.; Wilde, C.; Franke, P.; Mehta, N.; Cameotra, S.S. Matrix-assisted laser desorption ionization-time of flight mass spectrometry of lipopeptide biosurfactants in whole cells and culture filtrates of Bacillus subtilis C-1 isolated from petroleum sludge. Appl. Environ. Microbiol. 2002, 68, 6210-6219. [CrossRef]

39. Vater, J.; Xuewen, G.; Gabriele, H.; Christopher, W.; Peter, F. “Whole Cell” Matrix-Assisted Laser Desorption Ionization-Time of Flight-Mass Spectrometry, an Emerging Technique for Efficient Screening of Biocombinatorial Libraries of Natural Compounds-Present State of Research. Comb. Chem. High. Throughput Screen. 2003, 6, 557-567. [CrossRef]

40. Pueyo, T.M.; Mutafci, B.A.; Soto-Arriaza, M.A.; di Mascio, P.; Carmona-Ribeiro, A.M. The Self-Assembly of a Cyclic Lipopeptides Mixture Secreted by a B. megaterium Strain and Its Implications on Activity against a Sensitive Bacillus Species. PLoS ONE 2014, 9, e97261. [CrossRef]

41. Hossain, A.; Masum, M.M.I.; Wu, X.; Abdallah, Y.; Ogunyemi, S.O.; Wang, Y.; Sun, G.; Li, B.; An, Q. Screening of Bacillus strains in biocontrol of pathogen Dickeya dadantii causing stem and root rot disease of sweet potato. Biocontrol Sci. Technol. 2020, 30. [CrossRef]

42. Sarwar, A.; Hassan, M.N.; Imran, M.; Iqbal, M.; Majeed, S.; Brader, G.; Sessitsch, A.; Hafeez, F.Y. Biocontrol activity of surfactin A purified from Bacillus NH-100 and NH-217 against rice bakanae disease. Microbiol. Res. 2018, 209, 1-13. [CrossRef] [PubMed]

43. Chen, H.; Wang, L.; Su, C.X.; Gong, G.H.; Wang, P.; Yu, Z.L. Isolation and characterization of lipopeptide antibiotics produced by Bacillus subtilis. Lett. Appl. Microbiol. 2008, 47, 180-186. [CrossRef] [PubMed]

44. Perez, J.K.; Viana, J.D.; Lopes, F.C.; Pereira, J.Q.; Santos, D.M.D.; Oliveira, J.S.; Velho, R.V.; Crispim, S.M.; Nicoli, J.R.; Brandelli, A.; et al. Bacillus spp. Isolated from Puba as a Source of Biosurfactants and Antimicrobial Lipopeptides. Front. Microbiol. 2017, 8, 61. [CrossRef]

45. Pathak, V.K.; Bose, A.; Keharia, H. Characterization of Novel Lipopeptides Produced by Bacillus tequilensis P15 Using Liquid Chromatography Coupled Electron Spray Ionization Tandem Mass Spectrometry (Lc ESI MS/MS). Int. J. Pept. Res. Ther. 2013, 20, 133-143. [CrossRef]

46. Pathak, K.V.; Keharia, H. Identification of surfactins and iturins produced by potent fungal antagonist, Bacillus subtilis $\mathrm{K} 1$ isolated from aerial roots of banyan (Ficus benghalensis) tree using mass spectrometry. 3 Biotech 2014, 4, 283-295. [CrossRef]

47. Stein, T. Whole-cell matrix-assisted laser desorption/ionization mass spectrometry for rapid identification of bacteriocin/lantibiotic-producing bacteria. Rapid Commun. Mass Spectrom. 2008, 22, 1146-1152. [CrossRef]

48. Wang, X.; Li, Q.; Sui, J.; Zhang, J.; Liu, Z.; Du, J.; Xu, R.; Zhou, Y.; Liu, X. Isolation and Characterization of Antagonistic Bacteria Paenibacillus jamilae HS-26 and Their Effects on Plant Growth. Biomed. Res. Int. 2019. [CrossRef] 
49. Wardle, A.D.; Bardgett, R.D.; Klironomos, J.N.; Setälä, H.; van der Putten, W.H.; Wall, D.H. Ecological Linkages Between Aboveground and Belowground Biota. Science 2004, 304, 1629-1633. [CrossRef]

50. Berg, G.; Smalla, K. Plant species and soil type cooperatively shape the structure and function of microbial communities in the rhizosphere. FEMS Microbiol. Ecol. 2009, 68, 1-13. [CrossRef]

51. Stein, T. Bacillus subtilis antibiotics: Structures, syntheses and specific functions. Mol. Microbiol. 2005, 56, 845-857. [CrossRef]

52. Collins, P.D.; Jacobsen, B.J. Optimizing a Bacillus subtilis isolate for biological control of sugar beet cercospora leaf spot. Biol. Control 2003, 26, 153-161. [CrossRef]

53. Gardener, B.M.M. Ecology of Bacillus and Paenibacillus spp. in Agricultural Systems. Phytopathology 2004, 94, 1252-1258. [CrossRef]

54. Raupach, S.G.; Kloepper, J.W. Mixtures of Plant Growth-Promoting Rhizobacteria Enhance Biological Control of Multiple Cucumber Pathogens. Phytopathology 1998, 88, 1158-1164. [CrossRef] [PubMed]

55. Shoda, M. Bacterial control of plant diseases. J. Biosci. Bioeng. 2000, 89, 515-521. [CrossRef]

56. Romero, D.; Pérez-García, A.; Rivera, M.E.; Cazorla, F.M.; de Vicente, A. Isolation and evaluation of antagonistic bacteria towards the cucurbit powdery mildew fungus Podosphaerafusca. Appl. Microbiol. Biotechnol. 2004, 164, 263-269. [CrossRef]

57. Raaijmakers, M.J.; Vlami, M.; de Souza, J.T. Antibiotic production by bacterial biocontrol agents. Antonie Leeuwenhoek 2002, 81, 37. [CrossRef]

58. Schisler, A.D.; Slininger, P.J.; Behle, R.W.; Jackson, M.A. Formulation of Bacillus spp. for Biological Control of Plant Diseases. Phytopathology 2004, 94, 1267-1271. [CrossRef]

59. Ongena, M.; Jacques, P.; Touré, Y.; Destain, J.; Jabrane, A.; Thonart, P. Involvement of fengycin-type lipopeptides in the multifaceted biocontrol potential of Bacillus subtilis. Appl. Microbiol. Biotechnol. 2005, 69, 29-38. [CrossRef]

60. Sellem, I.; Triki, M.A.; Elleuch, L.; Cheffi, M.; Chakchouk, A.; Smaoui, S.; Mellouli, L. The use of newly isolated Streptomyces strain TN258 as potential biocontrol agent of potato tubers leak caused by Pythium ultimum. J. Basic Microbiol. 2017, 57, 393-401. [CrossRef] [PubMed]

61. Adams, D.J. Fungal cell wall chitinases and glucanases. Microbiology 2004, 150, 2029-2035. [CrossRef] [PubMed]

62. Shrestha, A.; Sultana, R.; Chae, J.-C.; Kim, K.; Lee, K.-J. Bacillus thuringiensis C25 which is rich in cell wall degrading enzymes efficiently controls lettuce drop caused by Sclerotinia minor. Eur. J. Plant. Pathol. 2015, 142, 577-589. [CrossRef]

63. Khan, N.; Martínez-Hidalgo, P.; Ice, T.A.; Maymon, M.; Humm, E.A.; Nejat, N.; Sanders, E.R.; Kaplan, D.; Hirsch, A.M. Antifungal Activity of Bacillus Species against Fusarium and Analysis of the Potential Mechanisms Used in Biocontrol. Front. Microbiol. 2018, 9, 2363. [CrossRef] [PubMed]

64. Li, H.; Guan, Y.; Dong, Y.; Zhao, L.; Rong, S.; Chen, W.; Lv, M.; Xu, H.; Gao, X.; Chen, R.; et al. Isolation and evaluation of endophytic Bacillus tequilensis GYLH001 with potential application for biological control of Magnaporthe oryzae. PLoS ONE 2018, 13, e203505. [CrossRef] [PubMed]

65. Hazarika, J.D.; Goswami, G.; Gautom, T.; Parveen, A.; Das, P.; Barooah, M.; Boro, R.C. Lipopeptide mediated biocontrol activity of endophytic Bacillus subtilis against fungal phytopathogens. BMC Microbiol. 2019, $19,71$. [CrossRef] [PubMed]

66. Asaka, O.; Shoda, M. Biocontrol of Rhizoctonia solani Damping-Off of Tomato with Bacillus subtilis RB14. Appl. Environ. Microbiol. 1996, 62, 4081-4085. [CrossRef] [PubMed]

67. Koumoutsi, A.; Chen, X.-H.; Henne, A.; Liesegang, H.; Hitzeroth, G.; Franke, P.; Vater, J.; Borriss, R. Structural and functional characterization of gene clusters directing nonribosomal synthesis of bioactive cyclic lipopeptides in Bacillus amyloliquefaciens strain FZB42. J. Bacteriol. 2004, 186, 1084-1096. [CrossRef] [PubMed]

68. Romero, D.; de Vicente, A.; Rakotoaly, R.H.; Dufour, S.E.; Veening, J.W.; Arrebola, E.; Cazorla, F.M.; Kuipers, O.P.; Paquot, M.; Pérez-García, A. The iturin and fengycin families of lipopeptides are key factors in antagonism of Bacillus subtilis toward Podosphaera fusca. Mol. Plant. Microbe Interact. 2007, 20, 430-440. [CrossRef]

69. Jiang, J.; Gao, L.; Bie, X.; Lu, Z.; Liu, H.; Zhang, C.; Lu, F.; Zhao, H. Identification of novel surfactin derivatives from NRPS modification of Bacillus subtilis and its antifungal activity against Fusarium moniliforme. BMC Microbiol. 2016, 16, 31. [CrossRef] 
70. Gong, -D.A.; Li, H.-P.; Yuan, Q.-S.; Song, X.-S.; Yao, W.; He, W.-J.; Zhang, J.-B.; Liao, Y.-C. Antagonistic Mechanism of Iturin A and Plipastatin A from Bacillus amyloliquefaciens S76-3 from Wheat Spikes against Fusarium graminearum. PLoS ONE 2015, 10, e0116871.

71. Leclère, V.; Béchet, M.; Adam, A.; Guez, J.-S.; Wathelet, B.; Ongena, M.; Thonart, P.; Gancel, F.; Chollet-Imbert, M.; Jacques, P. Mycosubtilin Overproduction by Bacillus subtilis BBG100 Enhances the Organisms Antagonistic and Biocontrol Activities. Appl. Environ. Microbiol. 2005, 71, 4577. [CrossRef] [PubMed]

72. Munimbazi, C.; Bullerman, L.B. Isolation and partial characterization of antifungal metabolites of Bacillus pumilus. J. Appl. Microbiol. 1998, 84, 959-968. [CrossRef] [PubMed]

73. Nagórska, K.; Bikowski, M.; Obuchowski, M. Multicellular behaviour and production of a wide variety of toxic substances support usage of Bacillus subtilis as a powerful biocontrol agent. Acta Biochim. Pol. 2007, 54, 495-508. [CrossRef] [PubMed]

Publisher's Note: MDPI stays neutral with regard to jurisdictional claims in published maps and institutional affiliations.

(C) 2020 by the authors. Licensee MDPI, Basel, Switzerland. This article is an open access article distributed under the terms and conditions of the Creative Commons Attribution (CC BY) license (http://creativecommons.org/licenses/by/4.0/). 